\title{
A prospective observational evaluation of treatment outcomes of patients with chronic obstructive pulmonary disease and peripheral blood eosinophilia
}

\author{
Nuri TUTAR ${ }^{1}$ (ID) \\ Figen ARSLANTAŞ ${ }^{1}$ (ID) \\ Burcu BARAN \\ KETENCIOĞLU ${ }^{1}($ ID) \\ İnsu YILMAZ ${ }^{2}$ (ID) \\ Fatma Sema OYMAK ${ }^{1}(I D)$ \\ İnci GÜLMEZ ${ }^{1}$ (ID)
}

${ }^{1}$ Department of Chest Diseases, Erciyes University Faculty of Medicine, Kayseri, Turkey

${ }^{1}$ Erciyes Üniversitesi Tıp Fakültesi, Göğüs Hastalıkları Anabilim Dalı, Kayseri, Türkiye

${ }^{2}$ Division of Allergy and Immunology, Department of Chest Diseases, Erciyes University Faculty of Medicine, Kayseri, Turkey

${ }^{2}$ Erciyes Üniversitesi Tıp Fakültesi, Göğüs Hastalıkları Anabilim Dalı, Alerji ve Immünoloji Bilim Dalı, Kayseri, Türkiye
Cite this article as: Tutar $N$, Arslantaș F, Baran Ketencioğlu B, Yılmaz i, Oymak FS, Gülmez i. A prospective observational evaluation of treatment outcomes of patients with chronic obstructive pulmonary disease and peripheral blood eosinophilia. Tuberk Toraks 2021;69(4):477-485

\section{Yazışma Adresi (Address for Correspondence)}

\section{Dr. Nuri TUTAR}

Department of Chest Diseases,

Erciyes University Faculty of Medicine

KAYSERI - TURKEY

e-mail: drnuritutar@gmail.com

CCopyright 2021 by Tuberculosis and Thorax.

Available on-line at www.tuberktoraks.org.com

\begin{abstract}
A prospective observational evaluation of treatment outcomes of patients with chronic obstructive pulmonary disease and peripheral blood eosinophilia

Introduction: This study aimed to compare two groups of patients with Chronic Obstructive Lung Disease (COPD) and blood eosinophil values of $\geq 300$ cells/ $\mu \mathrm{L}$. The patients were followed up for one year in two groups, one receiving inhaled corticosteroids (ICS) and the other not receiving ICS in terms of exacerbation rates, the incidence of pneumonia, mortality rates, FEV,$F V C$ and FEF ${ }_{25-75}$ changes, the COPD Assessment Test (CAT) and modified Medical Research Council (mMRC) dyspnea scores.
\end{abstract}

Materials and Methods: Stable patients, who presented to the University Medical Faculty Chest diseases outpatient clinic and diagnosed with COPD according to pulmonary function test results and GOLD stages 2-4 according to the 2017 GOLD criteria and with blood eosinophil counts of $\geq 300$ cells/ $\mu L$ were included in the study.

Results: 85 patients were included in the study, of which $76.5 \%(n=65)$ were males. There were no significant differences between the 38 patients receiving ICS and the 47 patients not receiving ICS regarding baseline FEV $, F V C, F E F_{25}$ 75 absolute values and percentages, and FEV,$F V C$ values controlled at month six and month 12, and FEF ${ }_{25-75}$ absolute values and percentages at month six ( $p>0.05)$. However, the difference between the baseline and month 12 absolute values and percentages of $F E F_{25-75}$ was statistically significant, and the decrease from baseline was greater in the group receiving ICS $(p<0.05)$. The difference in CAT and $m M R C$ scores were statistically significant at month six and month nine in favor of the group receiving ICS $(p<0.05)$. The median 
number of moderate and severe exacerbations were both one (min: 0, max:3) in the group receiving ICS ( $n=38$ ) and in the one not receiving ICS $(n=47)$. The difference of exacerbation rates in both groups were not statistically significant $(p>0.05)$.

Conclusion: In this study, it was determined that exacerbation rates of eosinophilic COPD patients did not differ depending on the use of ICS in a one-year period. Nevertheless, the 12-month FEF ${ }_{25-75}$ values of patients not using ICS were lower to a lesser extent, while the CAT and mMRC scores improved in favor of ICS users at different months in the one-year follow-up.

Key words: COPD; eosinophilia; exacerbation

ÖZ

Kronik obstrüktif akciğer hastalığı ve periferik kan eozinofilisi olan hastaların tedavi sonuçlarının prospektif gözlemsel değerlendirilmesi

Giriş: Bu çalışmanın amacı; KOAH'ı ve kan eozinofil değerinin $\geq 300$ hücre/ $\mu$ L olan hastaların iki gruba ayrılarak inhaler kortikosteroid (IKS) alan ve almayan olarak 1 yıl boyunca takip edilmesi ile, alevlenme oranı, pnömoni sıklığı, mortalite, CAT, mMRC skoru, $\mathrm{FEV}_{1}$, FVC ve $\mathrm{FEF}_{25-75}$ değişimini karşılaştırmaktır.

Materyal ve Metod: Erciyes Üniversitesi Tıp Fakültesi Gögüs Hastalıkları polikliniğine başvuran, solunum fonksiyon testi bulguları ve GOLD 2017 kriterlerine göre KOAH tanısı alan, GOLD grade 2-4 olan ve kan eozinofili değeri $\geq 300$ hücre/ $\mu$ L olan stabil hastalar çalışmaya alındı.

Bulgular: Çalışmaya 85 hasta alındı ve bunların \%76,5'i (n=65) erkekti. iKS alan 38 hasta ve almayan 47 hasta grubu arasında başlangıç $F E V_{1}, F V C, F E F_{25-75}$ mutlak değer ve yüzdesi ile kontrol edilen 6. ay ve 12. ay $F E V_{1}$, FVC ve 6. ay $F E F_{25-75}$ mutlak ve yüzde değeri arasında istatistiksel anlamlı fark izlenmemiştir $(p>0,05)$. Başlangıç $F E F_{25-75}$ mutlak değer ve yüzdesi ile kontrol edilen 12. ay değerler arasında istatistiksel olarak anlamlı fark olup başlangıç değerine göre iKS alan grupta iKS almayan gruba göre daha fazla azalma mevcuttur $(p<0,05)$. CAT ve mMRC skoru farkı 6. ve 9. ayda iKS alan grup lehine istatistiksel olarak anlamlıdır $(p<0,05)$. Hem IKS alan grupta hem de iKS almayan grupta ortalama ağır ve orta alevlenme sayısı $1(\min =0, \max =3)$ idi. iki grup arasındaki alevlenme sayısı istatistiksel olarak anlamlı değildi $(p>0,05)$.

Sonuç: Sonuç olarak bu çalışma ile eozinofilik KOAH hastalarının bir yıllık süre zarfında iCS kullanıp kullanmamasına göre alevlenme sıklığının değişmediği saptanmıştır. Bununla beraber iCS kullanmayan hastaların 12. ayda FEF ${ }_{25-75}$ değeri daha az düşerken, CAT ve mmRC skorlarının 1 yıllık takipteki farklı aylarda iCS kullanan hastalar lehine iyileştiği görülmüştür.

Anahtar kelimeler: $K O A H$; eozinofili; alevlenme

\section{INTRODUCTION}

According to WHO estimates, 65 million people have moderate to severe chronic obstructive pulmonary disease (COPD). Estimates show that COPD will become the third leading cause of death worldwide by 2030 (1). After COPD is diagnosed, effective management should be based on an individualized assessment in order to decrease both the present symptoms and risk of future exacerbations. An individualized approach is recommended to start and increase/decrease the treatment of the patient depending on the level of symptoms, and exacerbation risk (2). Continuous follow-up should include continuous assessment of exposure to risk factors and monitoring disease progression, effects and possible adverse effects of treatment, history of exacerbations and comorbidities (2). Therefore, long-term management of COPD over the years is planned not only according to the stages of the disease but also according to phenotype.
Eosinophils are cells capable of digesting bacteria, fungi, inert particles, and antigen-antibody complexes, which show their effects by releasing cellular contents (3). Presence of $250-1500 / \mathrm{mm}^{3}$ eosinophils in peripheral blood is considered mild eosinophilia, while presence of $1500-5000 / \mathrm{mm}^{3}$ and $>5000 / \mathrm{mm}^{3}$ are considered moderate and severe eosinophilia, respectively (4). The treatment of eosinophilic COPD is not entirely clear. Several recent studies have shown the inhibitory effect of inhaled corticosteroid (ICS) (added to regular maintenance bronchodilator therapy) on future exacerbations by monitoring blood eosinophil counts (5-10). The therapeutic effect of ICS containing regimens [ICS + long-acting muscarinic receptor antagonist (LAMA) + long-acting $\beta$-agonist $(\mathrm{LABA})$ ] are superior to LABA + LAMA on hospitalization in patients who had at least one exacerbation in the previous year (7). In another study, eosinophil counts were compared among LABA+LAMA combination and ICS+LABA combination. LABA+LAMA provides superior or similar benefits over salmeterol/ 
fluticasone regardless of blood eosinophil levels in patients with COPD (11). The differences between the studies suggest that more data is needed in this group of patients.

Therefore, we aimed to separate COPD patients with blood eosinophil counts $\geq 300$ cells/ $\mu \mathrm{L}$ into two groups as those receiving and not receiving ICS, to find the rates of exacerbations, pneumonia incidence, and mortality during a one-year follow-up and to compare the COPD Assessment Test (CAT) and modified Medical Research Council (mMRC) dyspnea scores, changes in $\mathrm{FEV}_{1}, \mathrm{FVC}$ and $\mathrm{FEF}_{25-75}$ values.

\section{MATERIALS and METHODS}

\section{Patient Selection}

Stable COPD patients aged above 40 years, smoking at least 10 packs/year cigarettes or with biomass exposures who presented to the Chest Diseases outpatient clinic at the University Medical Faculty and who were diagnosed with COPD according to pulmonary function test results $\left(\mathrm{FEV}_{1} / \mathrm{FVC}\right.$ values below 0.7 post-bronchodilator and negative reversibility $\left(>12 \%\right.$ or $>200 \mathrm{ml}$ improvement in $\mathrm{FEV}_{1}$ measured after $400 \mu \mathrm{g}$ salbutamol inhalation) and the GOLD 2017 criteria. Those who were GOLD stages 2-4 and had blood eosinophil counts $\geq 300$ cells/ $\mu \mathrm{L}$ were included into the study between January 2018 to July 2019 (12). Patients who concomitantly had asthma, eosinophilia-causing vasculitis, Loeffler's syndrome, allergic bronchopulmonary aspergillosis, parasitic diseases, exacerbations within the last four weeks and who used oral steroids in the last four weeks were excluded from the study. Approval was obtained from the Ethics Committee of Erciyes University Medical Faculty before the study (Ethics committee consent no: 2017-453). Each patient included in the study signed a patient informed consent form explaining in detail the procedures to be performed during the study (Supplement 1- study group consent form).

The patients were separated into two groups according to the use of inhaled corticosteroids or not: Group $1(n=38)$ comprised patients using inhaled corticosteroids (receiving ICS) and Group $2(n=47)$ patients not using inhaled corticosteroids (not receiving ICS). The daily ICS regimens were budesonide $640 \mathrm{mcg}$ or $800 \mathrm{mcg}$, fluticasone propionate 1000 $\mathrm{mcg}$, beclomethasone dipropionate $400 \mathrm{mcg}$ and fluticasone furoate $100 \mathrm{mcg}$. Treatment of the patients was planned by the physicians at the outpatient clin- ic, and there was no intervention for the treatment on our side. The patients were prospectively observed for one year. Their PFT values, hemogram values, CAT scores, mMRC scores, number of exacerbations and histories were inquired and recorded at baseline. Three months later, CAT scores, mMRC scores, number of exacerbations, and mortality were inquired and recorded via phone calls. At the six-month control visit, PFT values, hemogram values, CAT scores, mMRC scores, number of exacerbations and mortality were inquired and recorded. At month nine, CAT scores, mMRC scores, number of exacerbations and deaths were inquired via phone calls and recorded. At the 12-month control, PFT values, hemogram values, CAT scores, mMRC scores, number of exacerbations and mortality were inquired and recorded.

Moderate and severe exacerbations were recorded. Moderate exacerbation was defined as the condition where the patient was treated (short-acting $\beta 2$ agonists) SABAs plus antibiotics and/or oral corticosteroids. In contrast, a severe exacerbation was defined as the condition where the patient required hospitalization or visits to the emergency room (12). Severe exacerbations may also be associated with acute respiratory failure. Pneumonia was diagnosed according to clinical and radiological criteria.

\section{Assessment of Comorbidities}

The comorbidities of the patients were asked and recorded.

\section{Evaluation of CAT and mMRC Scores}

A questionnaire including questions about CAT and mMRC was applied to the patients, and the total score was recorded.

\section{Pulmonary Function Test}

Pulmonary function tests were performed at the Erciyes University Medical Faculty Chest Diseases outpatient clinic by trained and experienced respiratory function test technicians of at least five years using a Vmax 20c spirometer device while the patients were in a sitting position. Following at least three maneuvers of the pulmonary function test, the best result was recorded. At baseline, the first PFT was performed with bronchodilators to rule out the diagnosis of asthma, and another PFT (without bronchodilators) was performed in the sixth and 12th month. Patients diagnosed with COPD were separated into groups A, B, C and D according to GOLD 2017 criteria and CAT, mMRC scores, number of 
attacks and history of hospitalizations were recorded (12).

\section{Hemogram}

According to the results of the hemogram studied at the central laboratory of Erciyes University Medical Faculty Hospital, patients' white blood cell counts, hemoglobin, eosinophil percentages, and absolute values at baseline, and sixth and $12^{\text {th }}$ months were recorded.

\section{Statistical Analysis}

SPSS software (Statistical Package for the Social Sciences, 22.0 version; SSPS Inc., Chicago, Illinois, USA) was used for statistical analysis. The distribution of continuous variables was tested with one-sample Kolmogorov-Smirnov Test; data were given as mean value \pm standard deviation or median, minimum-maximum ranges. Categorical variables were reported as frequency and group percentages. For the comparison of two groups, Student's t-test was used for parametric values, and the Mann-Whitney U-test was used for non-parametric values. The categorical variables were analyzed with the chi-square test. For comparisons of more than two groups, One-way ANOVA was used for parametric values and the Kruskal Wallis-Variance Analysis for non-parametric values. Exacerbation rates were analyzed by MannWhitney $U$ test and exacerbation percentages were analyzed by Pearson chi square test. All $\mathrm{p}$ values were two-sided, and $p$ values below 0.05 were considered significant.

\section{RESULTS}

85 patients with a mean age of $63.3 \pm 9.7$ years were included in the study. Of the patients, $76.5 \%(n=65)$ were males. Mean absolute eosinophil counts and percentages were $428.7 \pm 130.910^{3} / \mathrm{ml}$ and $5.1 \pm$ $1.4 \%$, respectively. Mean $\mathrm{FEV}_{1}$ values and percentages of the patients were $1886.4 \pm 658.1 \mathrm{ml}$ and $68 \pm$ $20 \%$, respectively. The inhaler therapies received by the patients, according to COPD groups, are given in the supplementary material. While 38 patients received (44.7\%) ICS, 47 (55.3\%) did not. There were no significant differences between the groups with and without ICS regarding sex, age, eosinophil counts, PFT parameters, and dyspnea scores ( $p>$ 0.05) (Table 1). The most frequent comorbidities were

Table 1. Comparison of both groups of patients included in the study in terms of age, smoking status, hemogram, blood eosinophil counts and PFT value

\begin{tabular}{|c|c|c|c|c|}
\hline Variables & $\begin{array}{l}\text { Total }(n=85) \\
(\text { mean } \pm \text { SD })\end{array}$ & $\begin{array}{c}\text { Group 1: with ICS } \\
\begin{array}{c}n=38) \\
(\text { mean } \pm S D)\end{array}\end{array}$ & $\begin{array}{c}\text { Group 2: without ICS } \\
\begin{array}{c}(n=47) \\
(\text { mean } \pm \text { SD })\end{array}\end{array}$ & $\mathbf{p}$ \\
\hline $\operatorname{Sex}(M / F)$ & $65 / 20$ & $27 / 11$ & $38 / 9$ & $>0.05$ \\
\hline Age (years) & $63.3 \pm 9.7$ & $61.4 \pm 10.8$ & $64.7 \pm 8.5$ & $>0.05$ \\
\hline Smoking (packs) & $41.2 \pm 22.5$ & $38.6 \pm 24.6$ & $43.2 \pm 20.7$ & $>0.05$ \\
\hline White cell count & $8160.2 \pm 1765.8$ & $8371.2 \pm 1796.9$ & $7989.6 \pm 1740.7$ & $>0.05$ \\
\hline Hemoglobin $(\mathrm{gr} / \mathrm{dl})$ & $14.9 \pm 1.81$ & $15.5 \pm 2$ & $14.7 \pm 1.6$ & $>0.05$ \\
\hline Eosinophil absolute $\left(10^{3} / \mathrm{mL}\right)$ & $428.7 \pm 130.9$ & $418.4 \pm 124.4$ & $437 \pm 136.7$ & $>0.05$ \\
\hline$\%$ Eosinophil & $5.1 \pm 1.4$ & $5 \pm 1.4$ & $5.2 \pm 1.4$ & $>0.05$ \\
\hline $\mathrm{FEV}_{1} / \mathrm{FVC}$ & $59.3 \pm 8.7$ & $58.9 \pm 9.6$ & $59.5 \pm 8$ & $>0.05$ \\
\hline $\mathrm{FEV}_{1}(\mathrm{~mL})$ & $1886.4 \pm 658.1$ & $1886.5 \pm 731.3$ & $1886.3 \pm 600.6$ & $>0.05$ \\
\hline$\% \mathrm{FEV}_{1}$ & $68 \pm 20$ & $67.2 \pm 21.9$ & $68.7 \pm 18.6$ & $>0.05$ \\
\hline $\mathrm{FVC}(\mathrm{mL})$ & $3120.2 \pm 895.3$ & $3127.8 \pm 1000$ & $3114 \pm 811.8$ & $>0.05$ \\
\hline$\% F V C$ & $87.7 \pm 20.1$ & $86.3 \pm 22.9$ & $88.9 \pm 17.7$ & $>0.05$ \\
\hline $\mathrm{FEF}_{25-75}(\mathrm{~L} / \mathrm{sn})$ & $963.4 \pm 456$ & $1003.4 \pm 483.6$ & $931 \pm 434.9$ & $>0.05$ \\
\hline$\% \mathrm{FEF}_{25-75}$ & $31.3 \pm 13.8$ & $31.3 \pm 13.4$ & $31 \pm 14.3$ & $>0.05$ \\
\hline Cat & $10(1-28)$ & $11(2-28)$ & $10(1-24)$ & $>0.05$ \\
\hline MMRC & $1(0-4)$ & $1(0-3)$ & $1(0-2)$ & $>0.05$ \\
\hline
\end{tabular}


Tutar N, Arslantaş F, Baran Ketencioğlu B, Yılmaz i, Oymak FS, Gülmez i.

Table 2. Comorbidities and their frequency in patients included in the study

\begin{tabular}{|lcc|}
\hline & Total $\mathbf{n =} \mathbf{8 5}$ & \% \\
\hline Patients with comorbidities & 77 & 90.6 \\
Hypertension & 43 & 50.6 \\
Diabetes mellitus & 24 & 28.2 \\
Coronary artery disease & 22 & 25.9 \\
Chronic renal failure & 8 & 9.4 \\
Malignancy & 5 & 5.9 \\
Rheumatoid arthritis & 3 & 3.5 \\
Congestive heart failure & 3 & 3.5 \\
Obstructive sleep apnea & 2 & 2.3 \\
No comorbidities & 8 & 9.4 \\
\hline
\end{tabular}

diabetes mellitus and hypertension, and there was not statistically difference between comorbidities in patients receiving ICS and not receiving ICS ( $p>0.05)$ (Table 2).

Regardless of the treatment received, $29.4 \%(n=25)$ of 85 patients included in the study were in Group $\mathrm{A}$, $38.9 \%(n=33)$ were in Group B, $16.5 \%(n=14)$ were in Group C, and $15.3 \%(n=13)$ were in Group D. There was no significant difference between the eosinophil absolute values and percentages of the COPD patients in Groups A, B, C and D; A $473.6 \pm$ $151.210^{3} / \mathrm{mL}(5.3 \pm 1.2 \%) ; \mathrm{B} 427.8 \pm 126.710^{3} / \mathrm{mL}$ $(5.3 \pm 1.5 \%) ; C \quad 378.5 \pm 95.910^{3} / \mathrm{mL}(4.8 \pm 1.3 \%) ; \mathrm{D}$ $398 \pm 115.610^{3} / \mathrm{mL}(4.6 \pm 1.5 \%) ; p>0.05$. The distribution of inhaler treatments received by patients according to COPD stages and the COPD groups of patients receiving and not receiving ICS are shown in Supplementary Table 1 and 2.

Median number of moderate and severe exacerbations were both one $(\min =0, \max =3)$ in the group receiving ICS $(n=38)$ and also in the group not receiving ICS $(n=47)$. The difference in exacerbation rates in both groups was not statistically significant (p> 0.05) (Table 3). There were $6(15.8 \%)$ cases of pneumonia in the group receiving ICS and also 6 $(12.8 \%)$ pneumonia cases in the group not receiving ICS ( $p>0.05)$. Two patients in the group not receiving ICS died in the first three-month period of the follow-up while no other deaths were recorded in the group receiving ICS (mortality $4.2 \%$ in the group not receiving ICS and $2.3 \%$ in total patients included in the study).

There was no statistically significant difference between baseline $\mathrm{FEV}_{1}$ and $\mathrm{FVC}$ absolute values and the $\mathrm{FEV}_{1}$ absolute values controlled in the $6^{\text {th }}$ and $12^{\text {th }}$ months of the patients included in the study receiving and not receiving ICS ( $p>0.05$ ). Again, there was no significant difference between baseline $\mathrm{FEF}_{25-75}$ absolute values and percentages, and the values controlled in the $6^{\text {th }}$ month $(p>0.05)$. However, there was a significant difference between the $\mathrm{FEF}_{25-75}$ absolute values and the values controlled in the $12^{\text {th }}$ month. The decrease from baseline was greater in the group receiving ICS $(-114.9 \pm$ $228.2 \mathrm{~mL}$ in the ICS group and $-87.1 \pm 241.7 \mathrm{~mL}$ in the non-ICS group) $(\mathrm{p}<0.05)$ (Table 4$)$.

Table 3. Numbers of exacerbations in the groups receiving and not receiving ICS

\begin{tabular}{|lccc|}
\hline Number of exacerbations & $\begin{array}{c}\text { Group 1: with ICS } \\
\mathbf{n = 3 8}(\boldsymbol{\%})\end{array}$ & $\begin{array}{c}\text { Group 2: without ICS } \\
\mathbf{n = 4 7}(\%)\end{array}$ & $\mathbf{p}$ \\
\hline 0 & $10(26.3 \%)$ & $9(19.1 \%)$ & \\
1 & $15(39.5 \%)$ & $22(46.8 \%)$ & $>0.05$ \\
2 & $8(21.1 \%)$ & $13(27.7 \%)$ & \\
3 & $5(13.2 \%)$ & $3(6.4 \%)$ & \\
\hline ICS: Inhaled corticosteroid. & & & \\
\hline
\end{tabular}


Table 4. Comparison between baseline $\mathrm{FEV}_{1}, \mathrm{FVC}$ and $\mathrm{FEF}_{25-75}$ values and the $6^{\text {th }}$ and $12^{\text {th }}$-month values in groups receiving and not receiving ICS

\begin{tabular}{|lccc|}
\hline PFT findings & $\begin{array}{c}\text { Group 1: } \text { with ICS } \\
(\mathbf{n = 3 8})\end{array}$ & $\begin{array}{c}\text { Group 2: without ICS } \\
(\mathbf{n = 4 5})\end{array}$ & $\mathbf{p}$ \\
\hline FEV $_{1}$ difference at month 6 & $-42.1 \pm 222.8$ & $-79.7 \pm 187.5$ & $>0.05$ \\
FEV $_{1}$ difference at month 12 & $-85.2 \pm 270.2$ & $-141.7 \pm 232.3$ & $>0.05$ \\
FVC difference at month 6 & $-100.8 \pm 326.4$ & $-116.6 \pm 256.5$ & $>0.05$ \\
FVC difference at month 12 & $-172 \pm 345.2$ & $-122.8 \pm 350.2$ & $>0.05$ \\
FEF $_{25-75}$ difference at month 6 & $-75 \pm 180.4$ & $-48 \pm 200$ & $>0.05$ \\
FEF $_{25-75}$ difference at month 12 & $-114.9 \pm 228.2$ & $-87.1 \pm 241.7$ & $<\mathbf{0 . 0 5}$ \\
\hline PFT: Pulmonary function test, ICS: Inhaled corticosteroids. & & \\
\hline
\end{tabular}

Table 5. The CAT, mMRC scores and differences in 3, 6, 9 and 12 months of patients receiving and not receiving ICS

\begin{tabular}{|c|c|c|c|}
\hline Variables & $\begin{array}{c}\text { Receiving ICS } \\
(\mathrm{n}=38) \\
\text { Median (min/max) }\end{array}$ & $\begin{array}{l}\text { Not receiving ICS } \\
\quad(n=45) \\
\text { Median }(\min / \max )\end{array}$ & $\mathbf{p}$ \\
\hline CAT $3^{\text {rd }}$ month & $0(-7 / 3)$ & $0(-6 / 5)$ & $>0.05$ \\
\hline CAT $6^{\text {th }}$ month & $-1(-11 / 6)$ & $0(-11 / 6)$ & $<0.05$ \\
\hline CAT $9^{\text {rd }}$ month & $-1(-13 / 10)$ & $1(-10 / 8)$ & $<0.05$ \\
\hline CAT $12^{\text {th }}$ month & $-1(-10 / 7)$ & $0(-12 / 4)$ & $>0.05$ \\
\hline $\mathrm{mMRC} 3^{\text {rd }}$ month & $0(-1 / 2)$ & $0(-1 / 1)$ & $>0.05$ \\
\hline $\mathrm{mMRC} 6^{\text {th }}$ month & $0(-2 / 1)$ & $0(-1 / 1)$ & $<0.05$ \\
\hline mMRC $9^{\text {rd }}$ month & $0(-2 / 2)$ & $0(-1 / 1)$ & $<0.05$ \\
\hline $\mathrm{mMRC} 12^{\text {th }}$ month & $0(-2 / 2)$ & $0(-2 / 1)$ & $>0.05$ \\
\hline
\end{tabular}

In groups receiving and not receiving ICS, median $(\mathrm{min} / \mathrm{max})$ differences in CAT were $-1(-11 / 6)$ and 0 $(-11 / 6)$ in the sixth month, and $-1(-13 / 10)$ and 1 $(-10 / 8)$ in the ninth month; on the other hand, median $(\mathrm{min} / \mathrm{max})$ differences in $\mathrm{mMRC}$ were $0(-2 / 1), 0$ $(-1 / 1)$ in the sixth month and $0(-2 / 2), 0(-2 / 1)$ in the ninth month $(p<0.05)$ (Table 5). Again, the differences in CAT and mMRC scores continued to decrease less in the $12^{\text {th }}$ month, but the difference was not significant ( $p>0.05)$.

Comparison of both groups in terms of PFT values, CAT, and mMRC scores of patients in COPD stages B, $\mathrm{D}$ are given in the supplemental material (Supplementary Tables 3-5).

\section{DISCUSSION}

In this study, the patients diagnosed with COPD and blood eosinophil counts $\geq 300$ cells/ $\mu \mathrm{L}$ were separated into two groups independent of the stage (those receiving and not receiving ICS), followed up for one year. No significant difference was found among them regarding the number of exacerbations, incidence of pneumonia, and decreases in $\mathrm{FEV}_{1}$ and $\mathrm{FVC}$ values. However, the $\mathrm{FEF}_{25-75}$ values yielded significant results in favor of the group not receiving ICS in the 12-month follow-up, and CAT and mMRC scores in favor of the group receiving ICS at certain months during follow-up. Two patients died in the non-ICS receiving group during the study and there was no mortality in the ICS receiving group.

The effect of blood eosinophil values on the rates of hospitalization for COPD exacerbation is still not clear. However, some retrospective and post-hoc analyses have revealed a relationship between higher rates of exacerbation and higher blood eosinophil counts, while other studies have noted lower rates of hospitalizations and exacerbations in COPD patients with high eosinophil levels (13-15). In the subgroup analyses of the FLAME study where the differences in the efficacies of ICS/LABA and LABA/LAMA in the 
prevention of exacerbations were analyzed according to blood eosinophil values during one year, fewer exacerbations were noted in favor of patients receiving LABA/LAMA therapy in groups with eosinophil values $<2 \%, 2-3 \%, 3-5 \%$ and counts $<150$ cells/ $\mu$ l.11 In a study comparing combination therapies of ICS/LABA and LABA/LAMA according to eosinophil percentages in COPD patients grouped as $<\% 2$ and $\geq 2 \%$, ICS/LABA combination has been found to be more efficient in the prevention of exacerbations in a follow-up longer than one year in patients with eosinophil levels $\geq 2 \%$ (16). In another randomized controlled study with similar results, ICS/LABA therapy has been found to be more effective than LABA therapy alone in the reduction of exacerbations in patients with blood eosinophil levels higher than $2.4 \%$ (17). Again, in another study comparing a triple treatment including ICS with a dual treatment not including ICS, the number of exacerbations was significantly reduced in favor of the group using ICS in patients with eosinophil levels higher than $2 \%$ (8). In our study, on the other hand, there was no significant difference between the groups receiving and not receiving ICS in terms of exacerbations in eosinophilic COPD patients. Our data also provide a different contribution to the literature, which includes contradictory data on this subject.

Also, some studies have found that ICS use increases pneumonia risk in COPD (18). In a recently performed network analysis, ICS use was shown to increase pneumonia risk in COPD patients with eosinophil counts below $100 / \mu \mathrm{L}$ and chronic bacterial infection (19). However, in the study by Pavord et al., ICS has not been shown to increase pneumonia risk, especially in COPD patients with eosinophilia levels greater than $2 \%(20)$. Again in our study, there was no significant increase in pneumonia incidence in patients using ICS in support of the literature because COPD patients with eosinophil counts above $300 / \mu \mathrm{L}$ were included in the study. This may be explained by the behavior of eosinophilic COPD patients as asthma.

The CAT and mMRC scores are used in the follow-up and staging of COPD patients (2). In a population-based study evaluating the efficiency of the CAT test in the assessment of COPD, 404 cases diagnosed with COPD among 6600 adults were evaluated (21). According to this study, the CAT score was found to determine the severity of symptoms better than $\mathrm{mMRC}$. However, mMRC is used more frequently in daily practice because it is more practical. When the CAT and mMRC scores of COPD patients in our study were analyzed, a significant difference was noted, especially in the $6^{\text {th }}$ and $9^{\text {th }}$ months. Nevertheless, when the difference in CAT and mMRC scores were compared among COPD stages of B and D in the $3^{\text {rd }}$, $6^{\text {th }}, 9^{\text {th }}$, and $12^{\text {th }}$ months, the difference in CAT and mMRC scores was found to be significant in the 6th month. This shows that the decrease in the severity of symptoms is seen prominently in the sixth month according to CAT and mMRC among symptomatic low (B) and high (D) risk stages. However, in a study, the total scores of St George's Respiratory Questionnaire (SGRQ) and the Transition Dyspnea Index in the $52^{\text {nd }}$ week improved more in patients using ICS and with eosinophil counts above 310 compared with the patients not using ICS (22). Whereas, in the subgroup analysis of the FLAME study, there was no significant difference in the SGRQ-C questionnaire scores of the patients with eosinophilia of greater than $2 \%$ between those who received ICS and those who did not (11).

There was no significant difference between baseline $\mathrm{FEV}_{1}$ absolute values and percentages and the $\mathrm{FEV}_{1}$ absolute values and percentages in the $6^{\text {th }}$ and $12^{\text {th }}$ month controls in the patients who did and did not receive ICS. However, $\mathrm{FEF}_{25-75}$ value was found to be significantly more reduced in the $12^{\text {th }}$ month in the group receiving ICS. These results show that the small airways did not get better in patients receiving ICS. However, there are confusing results in the PFT parameters in the literature about receiving ICS or not receiving ICS in patients with eosinophilic COPD. In a study comparing indacaterol/glycopyrronium with salmeterol + fluticasone, on the other hand, 52-week $\mathrm{FEV}_{1}$ loss was in favor of the patients not receiving ICS both in the patient group with eosinophil counts less than $2 \%$ and in the patient group with eosinophil counts greater than $2 \%(11)$. Nevertheless, in the analysis of the IMPACT study, it has been found that when patients with eosinophil counts above 310 used ICS, the loss in $\mathrm{FEV}_{1}$ was less (22). There are different results in different studies about pulmonary function test parameters in eosinophilic patients with ICS containing therapeutic regimens, and research will be continued on this subject in the future.

Different distinguishing data other than exacerbation and dyspnea scales are needed for planning therapy in COPD cases. Although eosinophil counts are one of them, many different studies with many patients 
yield different results. Perhaps a meta-analysis of these studies may provide benefit for this controversial subject.

As a limitation, the number of patients remained below our target. So, when we divided patients into four groups, such as COPD stages A, B, C, and D, the subgroups did not contain enough patients to compare within themselves. In addition, we did not divide the patients with moderate or severe exacerbations. So, we did not compare the groups with only moderate or severe exacerbations.

In conclusion, it was found in this study that the frequency of exacerbations did not differ depending on ICS use during the one-year follow-up in eosinophilic COPD patients. However, two patients died in the non-ICS group, and there was no mortality in ICS receiving group. Nevertheless, the $\mathrm{FEF}_{25-75}$ values of the patients not receiving ICS were better in the $12^{\text {th }}$ month, while CAT and mMRC scores improved in favor of the patients using ICS at different months during the one-year follow-up. This subject, which has still not been clarified, should be investigated with more studies.

Ethical Committee Approval: This study approval was obtained from Erciyes University Faculty of Medicine Ethics Committee (Decision No: 2017/453).

\section{CONFLICT of INTEREST}

The authors declare that they have no conflict of interest.

\section{AUTHORSHIP CONTRIBUTIONS}

Concept/Design: NT, IG, FSO

Analysis/Interpretation: FA, BBK

Data acqusition: FA

Writing: NT, iY

Clinical Revision: NT, BBK

Final Approval: FA

\section{REFERENCES}

1. World Health Organization (WHO) [homepage on the internet] Available from: https://www.who.int/respiratory/copd/burden/en/. Accessed: February 17, 2020.

2. Global Initiative for Chronic Obstructive Lung Disease. Global strategy for the diagnosis, management, and prevention of chronic obstructive pulmonary disease. 2019. Available from: http://goldcopd.org/. Access date: 22 June 2019.
3. Meeker DP. Pulmonary infiltrates and eosinophilia revisited. Cleve Clin J Med 1989; 56(2): 199-211.

4. DeBrosse CW, Rothenberg ME. Eosinophilia: clinical manifestations and therapeutic options. Allergy E-Book: Expert Consult Online and Print. 2011:361.

5. Siddiqui SH, Guasconi A, Vestbo J, Jones P, Agusti A, Paggiaro $P$, et al. Blood eosinophils: a biomarker of response to extrafine beclomethasone/formoterol in chronic obstructive pulmonary disease. Am J Respir Crit Care Med 2015; 192(4): 523-5.

6. Bafadhel M, Peterson S, De Blas MA, Calverley PM, Rennard SI, Richte $K$ et al. Predictors of exacerbation risk and response to budesonide in patients with chronic obstructive pulmonary disease: a post-hoc analysis of three randomized trials. Lancet Respir Med 2018; 6(2): 117-26.

7. Lipson DA, Barnhart F, Brealey N, Brooks J, Criner GJ, Day $N C$, et al. Once-daily single-inhaler triple versus dual therapy in patients with COPD. N Engl I Med 2018; 378(18): 1671-80.

8. Papi A, Vestbo J, Fabbri L, Corradi M, Prunier H, Cohuet G, et al. Extrafine inhaled triple therapy versus dual bronchodilator therapy in chronic obstructive pulmonary disease (TRIBUTE): a double-blind, parallel group, randomized controlled trial. Lancet 2018; 391(10125): 1076-84.

9. Pascoe S, Locantore N, Dransfield MT, Barnes NC, Pavord ID. Blood eosinophil counts, exacerbations, and response to the addition of inhaled fluticasone furoate to vilanterol in patients with chronic obstructive pulmonary disease: a secondary analysis of data from two parallel randomized controlled trials. Lancet Respir Med 2015; 3(6): 435-42.

10. Vestbo I, Papi A, Corradi M, Blazhko V, Montagna I, Francisco $C$, et al. Single inhaler extrafine triple therapy versus long-acting muscarinic antagonist therapy for chronic obstructive pulmonary disease (TRINITY): a double-blind, parallel group, randomized controlled trial. Lancet 2017; 389(10082): 1919-29.

11. Roche N, Chapman KR, Vogelmeier CF, Herth FJF, Thach $C$, Fogel $R$, et al. Blood eosinophils and response to maintenance chronic obstructive pulmonary disease treatment. Data from the FLAME trial. Am / Respir Crit Care Med 2017; 195(9): 1189-97.

12. Global Initiative for Chronic Obstructive Lung Disease. Global strategy for the diagnosis, management, and prevention of chronic obstructive pulmonary disease. 2017. Available from: http://goldcopd.org/. Accessed date: 22 June 2019.

13. Vedel-Krogh S, Nielsen SF, Lange P, Vestbo J, Nordestgaard BG. Blood eosinophils and exacerbations in chronic obstructive pulmonary disease. The Copenhagen General Population Study. Am J Respir Crit Care Med 2016; 193(9): 965-74.

14. Couillard S, Larivée P, Courteau J, Vanasse A. Eosinophils in $C O P D$ exacerbations are associated with increased readmissions. Chest 2017; 151(2): 366-73. 
15. Duman D, Aksoy E, Agca MC, Durmuş Koçak N, Ozmen $i$, Aktürk ÜA, et al. The utility of inflammatory markers to predict readmissions and mortality in COPD cases with or without eosinophilia. Int I Chron Obstruct Pulmon Dis 2015; 10: 2469-78.

16. Pavord ID, Lettis S, Locantore N, Pascoe S, Jones PW, Wedzicha JA, et al. Blood eosinophils and inhaled corticosteroid/long-acting $\beta-2$ agonist efficacy in COPD. Thorax 2016; 71(2): 118-25.

17. Hinds DR, Di Santostefano RL, Le HV, Pascoe S. Identification of responders to inhaled corticosteroids in a chronic obstructive pulmonary disease population using cluster analysis. BMJ open 2016; 6(6): e010099.

18. Crim C, Calverley PM, Anderson JA, Celli B, Ferguson GT, Jenkins $C$, et al. Pneumonia risk in COPD patients receiving inhaled corticosteroids alone or in combination: TORCH study results. Eur Respir I 2009; 34(3): 641-7.

19. Martinez-Garcia MA, Faner R, Oscullo G, de la Rosa D, Soler-Catalunâ J-J, Ballester $M$, et al. Inhaled Steroids, Circulating Eosinophils, Chronic Airway Infection and Pneumonia Risk in Chronic Obstructive Pulmonary Disease: A Network Analysis. Am I Respir Crit Care Med 2020 May 1; 201(9): 1078-85.
20. Pavord ID, Lettis S, Anzueto A, Barnes N. Blood eosinophil count and pneumonia risk in patients with chronic obstructive pulmonary disease: a patient-level meta-analysis. Lancet Respir Med 2016; 4(9): 731-741.

21. Cheng SL, Lin CH, Wang CC, Chan M-C, Hsu J-Y, Hang L-W, et al. Comparison between COPD Assessment Test (CAT) and modified Medical Research Council (mMRC) dyspnea scores for evaluation of clinical symptoms, comorbidities and medical resources utilization in COPD patients. J Formos Med Assoc 2019; 118(1 Pt 3): 429-35.

22. Pascoe S, Barnes N, Brusselle G. Blood eosinophils and treatment response with triple and dual combination therapy in chronic obstructive pulmonary disease: analysis of the IMPACT trial. Lancet Respir Med 2019; 7(9): 745-56. 